\title{
DOI https://doi.org/10.30525/978-9934-26-181-7-35
}

\section{ДЕМОГРАФГЧНА ПРОБЛЕМА: СУЧАСНИЙ СТАН ТА ШЛЯХИ ВИРІШЕННЯ}

\author{
Гандзій О. В. \\ викладач історії \\ Державний навчальний заклад «Вінницький иентр \\ професійно-технічної освіти переробної промисловості» \\ м. Вінниця, Украӥна
}

Протягом історичного розвитку людству доводилося долати численні глобальні перешкоди. Найактуальнішими нині стали демографічна, екологічна та продовольча проблеми, забруднення атмосфери, військові конфлікти. Вони стримують соціально-економічний розвиток і потребують великої кількості ресурсів. Тому над вирішенням згаданих проблем мають узгоджено працювати представники провідних країн.

Пропонуємо розглянути становище і шляхи подолання демографічної кризи. Це сукупність проблем, які призводять до різкого прискорення або порушення відтворення населення. Від них залежить майбутнє народів та держав.

У 1798 році англійський вчений Томас Роберта Мальтус у праці «Нариси про закони народонаселення» зазначив: «Народонаселення жорстко обмежене засобами існування. При цьому населення росте в геометричній прогресії, а засоби існування - в арифметичній. Враховуючи закон зі зменшення родючості земель, настане час, коли ресурсів для людства почне не вистачати».

Його прогноз почав втілюватися протягом ХX століття, різке збільшення кількості людей відбулося в країнах Азії. Вчені Римського клубу 1970-х роках на науковому рівні порушили проблему перенаселення Землі. Демографічна проблема планети знайшла своє відображення в наукових доповідях «Цілі для людства» Денніса Габора і «Межі зростання» Денніса і Донеллі Медоуз.

Крім Азії, високі темпи зростання чисельності населення спостерігаються у Африці. Найбільший приріст в 2019 році порівняно з 2018 роком зафіксували у Бахрейні, Нігерії, Екваторіальній Гвінеї, Омані, Уганді, Мальдівах, Анголі та Конго. Вчені прогнозують, що тенденції зростання кількості населення будуть зберігатися. Протягом 50 років чисельність населення Землі збільшиться на 2-3 мільярда, тобто до 9 мільярдів. Майже 
половину цього приросту припаде на Індію - 22 \%, Китай - $11 \%$, Пакистан, Нігерію та Індонезію - по 4\%.

Перенаселення викликає кризу продовольства. У пошуках харчів та роботи люди мігрують до великих міст. Там не можуть забезпечити мільйони бідняків якісним житлом. Тому вони формують цілі "пояси злиднів", як це можна побачити у Індії, посилюють безробіття, соціальне напруження в суспільстві, ріст злочинності.

Демографічний вибух в азійських країнах має значення для усієї планети. Люди мігрують. Це складний процес, який важко піддається методам прямого впливу. Він вимагає постійної уваги з боку держави, його слід враховувати при розробці економічної, соціальної, демографічної, етнокультурної та зовнішньої політики.

Мігрують найбільше у Європу. Через масовий наплив мігрантів 3'явилася загроза існуванню Шенгенської угоди. Протиріччя між країнами ЄС щодо розселення іноземців призводить до розколу Європейського Союзу. У 2015 році на вирішення проблем міграції Сврокомісія виділила 2,4 млрд євро. Із збільшенням мігрантів у Свропі зросла кількість терористичних актів, які організували представники Сходу. Терористичні, кримінальні та наркоутворення інтергувалися, вони фінансуються за рахунок оборудок $з$ наркотиками.

На відміну від Азії у Європі народжуваність менша, члени ЄС переживають демографічну кризу. Їх населення старше за жителів інших континентів. Таке становище може призвести до проблем 3 виплатою пенсій та соціальних допомог у майбутньому. Роботодавцями буде важче знайти висококваліфікований персонал, бракуватиме молоді, яка б розвивала державу, перебирала у свої руки керівництво. Статистичні дослідження показали, що показник смертності в 28 державах Європи перевищив показник народжуваності вперше з часів Другої світової війни. Населення ЄС зростає за рахунок імміграції з інших країн. Таку тенденцію прогнозують у найближчому майбутньому.

До демографічних проблем також відносять різні міжетнічні конфлікти, які призводять до воєн та погіршують політичну ситуацію у державі. Міжетнічне протистояння грунтується на боротьбі за владу. Такою була Громадянська війна в Південному Судані - збройний конфлікт між народами нуер та дінка, який розпочався після невдалого військового перевороту в грудні 2013 року. Війна принесла державі падіння курсу місцевої валюти, продовольчу кризу, багатотисячні жертви.

Найпоширеніша думка стосовно вирішення демографічної проблеми як у масштабах окремих країн, так і в цілому на планеті - планування народжуваності. Практично всі країни, що розвиваються, підтримують 
заходи, спрямовані на виконання міжнародної програми 3 планування сім'ї, - перешкоджають раннім шлюбам, стимулюють використання засобів контрацепції, сприяють залученню жінок до суспільно корисної діяльності. Цьому сприяють програми 3 народонаселення, що реалізуються під егідою ООН і супроводжуються міжнародною фінансовою допомогою.

Зниження народжуваності в економічно розвинених країнах сталося через те, що батьки віддають перевагу принципу: «якісно виростити 1-2 дітей». Такий підхід стає популярним і в країнах, що розвиваються.

Демографічна ситуація в країнах дуже тісно корелюється з якістю життя населення. У високо розвинутих країнах, з високим національним доходом на душу населення, рівнями освіти та охорони здоров'я, відтворення населення характеризується «простим» типом. У них витрачають на освіту 5-6 \% ВВП. У країнах, що розвиваються, витрати на освіту 1-2 \% ВВП. Іще важлива тривалість навчання, особливо для дівчаток. Існує зворотний зв' язок між тим скільки вони витрачають часу на здобуття освіти, й кількістю народжуваних пізніше ними дітей. Збільшення термінів навчання жінок - один зі шляхів до зниження народжуваності.

Всі складові демографічної проблеми пов'язані і взаємозалежні перенаселення, міграції, «старіння» нації, міжетнічні сутички. Вони відіграють важливу роль у житті планети. Над пошуком шляхів для виходу з демографічної кризи мають працювати уряди усіх країн. Тільки так можна запобігти фатальним наслідкам для людства.

\section{Література:}

1. Статистична служба Європейського Союзу Eurostat. URL: http://ec.europa.eu/eurostat

2. Рейтинг країн світу за чисельністю населення. Центр гуманітарних технологій. 2020. URL: https://gtmarket.ru/ratings/world-population

3. Грибіненко О.М. Економічна безпека країн світу в контексті сталого розвитку : монографія. Дніпро : Середняк Т.К., 2020, 434 с.

4. International Organization for Migration. URL: https://www.iom.int/

5. Demography and security. Proceedings of a workshop. Edited by Laurent Murawiec, David Adamson. - Paris.: RAND Corporation, 2001. -26 p. 